\title{
Effectiveness of Collaborative Writing among Secondary School Students in an ESL Classroom
}

\author{
Prathibarani Veramuthu, Parilah Md Shah \\ Beaconhouse Sri Lethia, Klang Selangor, Universiti Kebangsaan Malaysia, Bangi, Malaysia \\ Email: pritzpurple@yahoo.com,drparila@gmail.com
}

How to cite this paper: Veramuthu, P., \& Shah, P. M. (2020). Effectiveness of Collaborative Writing among Secondary School Students in an ESL Classroom. Creative Education, 11, 54-67.

https://doi.org/10.4236/ce.2020.111004

Received: December 16, 2019

Accepted: January 11, 2020

Published: January 14, 2020

Copyright $\odot 2020$ by author(s) and Scientific Research Publishing Inc. This work is licensed under the Creative Commons Attribution International License (CC BY 4.0).

http://creativecommons.org/licenses/by/4.0/

(c) (i) Open Access

\begin{abstract}
This study reviews the effectiveness of collaborative writing among secondary school students in ESL classroom. Writing skill is regarded as the most difficult task in second language learning. Various strategies have been employed by both teachers and students to enhance writing competence. As the education system is intended to the requirement for 21 st century educational practices. Collaborative approach is one of the key elements. It marks the shift in pedagogical instruction. Collaborative learning is perceived as one of its approaches which aid ESL students to become proficient in writing. This study explores students' attitudes towards improving writing skills of ESL students via collaborative writing. This study involved 32 secondary school respondents from Klang, Selangor. The survey research data were gathered through a questionnaire to assess students' attitudes towards collaborative writing. It was evident that students were able to collaborate in writing lessons. The findings indicate that students showed positive attitude while writing collaboratively. Hence, this approach can be implemented by language teachers to enhance language teaching and learning.
\end{abstract}

\section{Keywords}

21st Century Learning, Collaborative Writing, ESL Students, Attitudes, Writing Skills

\section{Introduction}

Writing ability is essential in language learning. It is a perceptible means of communication which appears in a written form. Writing helps one to express ideas, thoughts and feelings. Writing skills play a prominent role in second language learning. According to Fareed et al. (2016), writing task is perceived as the most complex skill which requires practice. In second language learning, writing 
skills must be grasped through practices and experiences. In order to develop writing skill, one should be offered an adequate time. Besides that, competent writers are established through massive practices.

Writing skill is pigeon-holed as an intricate task. This intricate task necessitates writing conventions such as grammar knowledge, spelling, sentences structures and vocabulary. Creativity, organisation and imagination are essential aspects in producing an authentic and fine writing. Undoubtedly, writing skills involve cognitive ability. Nunan (1989) claims that writing is an extremely difficult cognitive activity which requires the learner to have control over various factors. It is a requisite to think and compose ideas to produce compositions. Writing skill is vital for academic success and employment; therefore, the writing competence should be mounted among the students.

English is one of the dominant languages in Malaysia. It is broadly used as the second language for majority of its people. English is recognised as a compulsory subject in both primary and secondary schools. The curriculum stipulates the three broad area of language use. They are interpersonal, intrapersonal and aesthetic. These areas cover all four language skills (listening, speaking, writing and reading). All these four skills are evaluated in all three public examinations at different level. Basically, writing skill is an important element which will be assessed in all three examinations. Certainly, writing skill carries the larger percentage of marks. At each level, the length and genre of writing task may vary. In both primary and secondary level, there are examination papers which exclusively gauge on students writing skill competency. In writing class, students are required to compose myriad sorts of texts. In primary level, students learn basic sentences construction and are tailed by note expansion. While in secondary level, students are introduced to informal and formal writing which includes blog, email, letter, descriptive, narrative, recount articles and report. Writing task necessitates to organisation of ideas coherently in a cohesive manner. Ultimately, writing is deliberated as significant in second language learning area.

Students are exposed to the language throughout the 11 years of schooling. Yet most Malaysian students have the least competence in writing skills, even though English has been taught for many years. Chitravelu et al. (2005) argued that students could not reach a satisfactory level of proficiency in writing. The Ministry of Education has highlighted its goal of equipping individuals to compete globally. The rethinking of SPM English must pass idea, it was suggested again. It also recorded that only 28 percent of students achieved at least a credit, particularly in reading and writing skills, at Cambridge 1119. CAMBRIDGE 1119 is a more rigid paper (2). It also claimed that A in SPM is equivalent to a B in Cambridge. Thus, writing is a great challenge in second language since second language learners are incompetent in writing because they do not learn as native speakers. There are several factors which are accountable for students' poor writing ability. Firstly, these students have limited varied and complex vocabulary and difficulty in combining grammatical forms due to interference from their mother tongue. This complicates the method of expressing ideas in written 
form. In addition, minimal reading skills and unprepared writing drafts have failed to produce skilful writing. Significant methods and techniques to teach writing skills are considered for all of these reasons discussed.

Great attention should be channelled towards enhancing students writing ability. The writing instruction should face a shift in an esl classroom. As the education system gears to the demand of 21 st century learning practices. Collaborative writing approach is definitely a good start. This approach provides scaffolding which is much necessary to enhance writing ability among students. Sukirman (2016) claimed collaboration is a technique used to promote writing through peer learning. Collaborative writing is effective in many respects if the classroom is introduced. Group writing helps students become better writers. A variety of phases (plan, write, revise and modify) are involved in collaborative writing. There is a requisite to perceive the effectiveness of collaborative approach. In view of the importance of integrating collaborative writing in classrooms, the attitudes of students towards collaborative writing need to be evaluated. Subsequently, there is a need to research whether collaborative writing is capable of developing both the students writing and their attitudes. According to Bulut (2017) attitude is one of the influential factor in writing skill. Students' positive attitude towards writing affects writing achievement. Hashemian and Heidari (2013) asserted that students with positive attitude capable of performing better in second language writing compared to those with negative attitudes. In response to this problem, the study will address the following research question.

1. What are the attitudes towards collaborative writing by ESL students?

\section{Literature Review}

\subsection{The Effectiveness of Collaborative Writing}

Collaborative writing is a process and contribution of ideas and effort from every group members at every stage of writing. Collaborative initiates at every beginning stage of writing, which include pre writing, drafting, revising and editing. Collaborative writing accentuates interactive teaching and learning, an exit from the more traditional, teacher-dominant classroom which has been the norm in Malaysia, Ong \& Maarof (2013). According to Murray (1992) collaborative writing is basically a social activity through which writers look for specific knowledge and view to be shared in order to produce essays. Every individual in the team is ought to held their responsibility over the production of writing. It involves sharing of knowledge, decision making and solving problems.

On other hand, collaborative writing is much needed as it is gaining its importance. Dale (1997) suggested it provides an atmosphere of cooperative learning in the aim to produce a good piece of writing. Through interdependence, students feel less unclear about the task; this may advantage those who needs assistance. Besides that, it promotes understanding for students to value each other's contribution. The tendency to build a safe social environment is high. Col- 
laborative writing may appear to be distinctive than other group work as the end the product is only one document shared among the peers.

There are number of advantages associated with collaboration approach in writing. Feedback possesses high potential to aid towards the goal to improve writing skill. Laal (2013) states collaborative learning naturally provides feedback and promotes a helpful setting within which to manage conflict resolution. When a student engages in writing individually, he/she may face difficulties in generating idea. Unlike collaborative writing, it prompts conversation among peers which gradually lead to feedback. Zhao (2010) claims feedback has been increasingly used in second language writing. It plays a crucial role in improving students writing skills. Bijami et al. (2013) cited Plutsky and Wilson (2004) providing feedback in writing activity aids students to become a proficient writer. Further asserted that, feedback also makes one to grow into a critical thinker. As for collaborative approach critical thinking is regarded as prominent, since problems in writing need to be answered.

Furthermore, collaborative writing creates opportunities to its member to interact. The interaction occurs when thoughts and opinions are shared. This approach is potential to escalate comprehension among peers about a task assigned. This is due to students' engagement in conversation. Continuous support among peers comes about throughout the writing process. Peers support is effective than teachers imparting knowledge about writing. Dale (1997) Students are capable to reveal ideas about writing when they co-author. Co-authoring is a strategy which is helpful for students who are not successful individualistic. Students are to enhance their interpersonal skills by interacting with each other.

Studies have revealed that collaborative writing has a great impact on motivation. While writing collaboratively, students work on many activities such as sharing knowledge and views and solving problems. At this point, students take charge of their own learning throughout the process. This leads to boost their self-confidence. Gradually, self-confidence will maximise motivation level in students. According to Farrah (2011) motivation is regarded as a crucial component of successful collaborative learning. Besides that, Ong \& Maarof (2013), mentioned students feel more contented with their classes and performance as they work in collaborative groups. Horwitz et al. (1997) agrees by claiming that collaborative learning increases self-confidence and decreases anxiety. In addition, Storch (2001) claims "group work will provide students with more opportunities to use the target language in low anxiety contexts", and this leads in decrease in anxiety and increase in motivation.

Collaborative writing allows learner to be more critical in their thinking process. Critical thinking is formed through problem solving process. It is nurtured through discussion and peers opinion and evaluation. Hussain (2004) advocated that incorporation of collaboration in learning make students enhance their creative thinking. Mandusic \& Blaskovi (2015) claimed critical thinking is improved and developed through collaboration. Critical thinking is regarded as one of the significant goals in learning and education. 


\subsection{Process Based Approach in Collaborative Writing}

In the context of in an ESL classroom, there is a great need to enhance second language learners writing skills. English is taught in both primary and secondary schools. Writing is one of the skills taught and tested besides listening, speaking and reading. In secondary school, esl students are exposed to both formal and informal varied forms of writing task. They are article, report, blog, emails, descriptive, narrative, recount and letters. All these writing task are conform to examination format. Therefore, students should master writing skill in order to be able to write all the various writing genres.

The second language writing issues have been debated over the years. This complex skill can be mastered with the right technique. As for an ordinary esl classroom, it is mostly consist of students with different literacy ability. Therefore, the domain of ESL writing instruction should encourage collaborative writing technique as it caters the need of the students. According to Vygotsky (1978), children perform better through peer interaction. Peer interaction provides opportunities for students to support and guide each other in learning. Weissberg (2006) claimed that collaborative task may be conducive than solitary writing. Students embrace several roles in developing writing competence in collaboration. They become tutors, co-authors and critical readers.

Widodo (2013) suggested supportive learning atmosphere is created when collaboration is integrated in process writing approach. While students work together in each stage of process writing approach, students tend experience the benefits collaboration. Hasan \& Akhand (2010) claimed that in ESL writing, process based approach is very significant. This approach stresses on the process of composing an essay. In this process students manage their own thinking, where they are given space to write what they think.

As process based approach involves many stages of writing. They are brainstorms, discussion and rewriting. At all stages, collaboration is integrated. For brainstorming, students get to pool ideas together. At this point students are negotiate and make shared decision. Besides that, students can share knowledge available with the members. Most prominently, there is an area to receive constructive feedback from the peers. Here the students get to evaluate the strength and weakness of their work. Hirashima et al. (2011) suggest process based writing approach is effective. It allows peer collaboration and group work at most of the stages.

\section{Methodology}

\subsection{Survey Design}

The study adopted a quantitative research. Data for this study was obtained by means of a questionnaire instrument. A survey aids to facilitate the process of gathering, evaluating and interpreting data from the respondents. In this study, a questionnaire tool was used to gather precise and authentic information from the targeted respondents. Therefore, it is hoped that the findings will illustrate 
the actual state of the ESL students' attitudes towards collaborative approach to enhance writing skill. In addition, the results of the study can also be generalized with the population accurately and effectively.

\subsection{Site}

The data for this study were collected from a secondary school based in Klang, Selangor. It is a renowned private school in Klang District. The school was chosen as the researcher is teaching in the school.

\subsection{Subjects}

The population for this study was lower secondary school students, consisting of one private secondary school. Purposive sampling was used in this study, which consists of 32 ESL students from form 2 English classes. According to Sharma (2017) purposive sampling is known as judgmental, selective or subjective sampling, represents a group of sampling techniques that rely on the researcher's judgment in the selection of units.

The respondents were both male and female ESL students. The rationale for this sample selection was that this batch of students is the pioneer batch introduced to CEFR framework which requires collaborative learning as part of 21 century learning. Therefore, it is hoped that information obtained from them are based on current scenario in Malaysian education.

\subsection{Instrument}

The researcher developed a set of questionnaires adapted from the previous study titled Attitudes towards Collaborative Writing among English Majors in Hebron University by Dr. Mohammed Abdel Hakim Farrah (2011). Some of the items were adopted from and adapted to suit the current study. The researcher developed a questionnaire which was appropriate for investigating attitudes towards collaborative learning. The questionnaire consisted of 32 statements with a 5 point Likert scale, (strongly agree, tend to agree, neutral, tend to disagree and strongly disagree).

The 32-item questionnaire was distributed at the end of the first semester of the academic year 2019. The questionnaire is used to stimulate the respondents' attitudes about their collaborative learning experiences. The researcher modified the questionnaire items according to the needs of this study. This questionnaire is divided into two sections, part A contains respondents' demographics of gender and age, part B is related to attitudes of students towards the incorporation collaborative approach in writing skills.

\subsection{Data Collection Procedure}

At the beginning of the first semester of academic year 2019, form 2 students were divided into groups consisting of five to six students per group. The aim is to make the students to write essays collaboratively throughout the semester. 
The students were given guiding principle for the written assignment .At the same time, during some English lessons, the students were requested to start writing the essays individually which includes brainstorm ideas, and then get to work in groups and make comparison of their writing with the other students in the group. In other classes, the students were assigned to brainstorm, organise ideas, draft, revise and edit together. They were given a number of topics of descriptive writing.

The goal of this procedure is to encourage the students to engage in an interaction which permits them to generate ideas and obtain additional feedback from the group members. During this process, the students were requested to discuss the problems in writing. Furthermore, the students were asked to produce remark on the content and organisation of the essays. In order to make sure that the students work effectively on such collaborative activities, guidelines for collaborative learning were taken into consideration. Thus, the teacher will ask the students about collaborative writing. The students will be given the option to choose their own group. The instruction is comprehensive to the students as for the need to work individually first, then in groups. Each group chooses a leader. The group leader's task is to manage the collaborative activities and provide encouragement throughout the session in order to submit draft timely for further discussion. Both individual and group work will be graded separately. The grading will be done for the final submission of classwork for the semester. This takes place upon the completion of the writing tasks, the students will be requested to fill out a questionnaire about the written task and the collaborative writing sessions to understand the significance of the writing process and the students' improvement in writing and their attitudes towards the collaborative approach.

\subsection{Data Analysis}

Data obtained from this study were analysed statistically using the Statistical Packages for the Social Sciences (SPSS) version 25. Statistical Packages for the Social Sciences (SPSS) is identify as computer software packages used to process and analyse research data. SPSS is built specifically to accommodate the rapid and efficient analysis of many and repetitive data. The findings are analysed descriptively.

Descriptive statistics is used to give a summary of the sample in terms of students' attitudes in the form of frequency mead, standard deviation and percentage. The researcher used the mean descriptive analysis and the standard deviation for each study construct on students' attitude.

\section{Findings \& Discussion}

A total of 32 respondents participated in this study. A questionnaire which consisted of 32 items was developed to collect descriptive data. The participants include 16 female and 16 male students. 
The following section aims at answering the following research question

1. What are the attitudes toward collaborative writing by ESL students?

Descriptive statistics (means and standard deviations) were calculated for all questionnaire items as to study the attitudes towards collaborative writing as perceived by ESL students (Table 1 displays the calculated means of items and their standard deviation for each statement).

Descriptive statistics of students' perceived attitudes who select to work in collaboration and understand better and learn better while working in groups. The findings illustrate that students have better response for collaborative writing activities. The result is presented in Table 1 in the form of percentage. Overall, the respondents (72\%) agreed that they learn better via collaborative learning technique.

Based on the result in Table 2, it shows that $34 \%$ of the respondents agreed that they prefer to write alone. About $67 \%$ agreed to prefer collaborative writing. The data shows that the students' interest for writing skill can be developed through collaborative writing.

As Table 3 reveals most of the items obtain high to moderate ratings. Firstly item $3(\mathrm{~m}=4.72)$ and $4(\mathrm{~m}=4.38)$ obtain the highest rating mean respectively. This implies that collaborative learning is a useful approach in enhancing problem solving skill. According to Maal (2012) collaborative learning creates societal responses towards problems and capable to manage conflict towards solution. Gohkale (1995) accentuates on the development of collaborative learning where one of the primary goal is problem solving skill. On the other hand item 4 (working in group stimulates critical thinking). Critical thinking skills is regarded as a significant element in Bloom's taxonomy in order to achieve higher thinking order. Ali (2018) reported collaborative writing provides platform for healthy argument via discussion, which demonstrates higher thinking abilities among students. Mandusic \& Blaskovic (2015) study aligned with the findings, critical thinking can be developed and enhanced through collaboration approach. It is observed as beneficial method in learning. Students develop this skill through discussion, clarification of ideas and evaluation.

Table 1 . When I study alone, I understand better and learn better.

\begin{tabular}{cccccc}
\hline & & Frequency & Percent & Valid Percent & Cumulative Percent \\
\hline \multirow{4}{*}{ Attitude } & YES & 9 & 28.1 & 28.1 & 28.1 \\
& NO & 23 & 71.9 & 71.9 & 100.0 \\
& Total & 32 & 100.0 & 100.0 & \\
\hline
\end{tabular}

Table 2. I prefer to write alone rather than in a group.

\begin{tabular}{cccccc}
\hline & & Frequency & Percent & Valid Percent & Cumulative Percent \\
\hline \multirow{4}{*}{ Attitude } & YES & 11 & 34.4 & 34.4 & 34.4 \\
& NO & 21 & 65.6 & 65.6 & 100.0 \\
& Total & 32 & 100.0 & 100.0 & \\
\hline
\end{tabular}


Table 3. Means and standard deviation for all items in the questionnaire.

\begin{tabular}{|c|c|c|c|c|}
\hline No & Statement & $\mathrm{N}$ & Mean & Std Deviation \\
\hline 1 & WORKING IN GROUPS INCREASED MY COMPREHENSION & 32 & 3.72 & 0.958 \\
\hline 2 & $\begin{array}{l}\text { WORKING IN GROUPS FOSTERED EXCHANGE OF KNOWLEDGE, INFORMATION AND } \\
\text { EXPERIENCE }\end{array}$ & 32 & 3.88 & 0.793 \\
\hline 3 & WORKING IN GROUPS MADE PROBLEM-SOLVING EASIER & 32 & 4.72 & 0.457 \\
\hline 4 & WORKING IN GROUPS STIMULATED MY CRITICAL THINKING SKILLS & 32 & 4.38 & 0.66 \\
\hline 5 & WORKING IN GROUPS HELPED ME TO WORK IN A MORE RELAXED ATMOSPHERE & 32 & 3.75 & 1.136 \\
\hline 6 & WORKING IN GROUPS HELPED ME TO RECEIVE USEFUL FEEDBACK & 32 & 4.31 & 0.693 \\
\hline 7 & $\begin{array}{l}\text { WORKING IN GROUPS HELPED ME TO FOCUS ON COLLECTIVE EFFORTS RATHER THAN } \\
\text { INDIVIDUAL EFFOR }\end{array}$ & 32 & 3.69 & 1.176 \\
\hline 8 & $\begin{array}{l}\text { WORKING IN GROUPS HELPED ME TO HAVE A GREATER RESPONSIBILITY - FOR MYSELF } \\
\text { AND THE GROUP }\end{array}$ & 32 & 3.69 & 1.176 \\
\hline 9 & WORKING IN GROUPS ENABLED US TO HELP WEAKER LEARNERS IN THE GROUP & 32 & 4 & 1.078 \\
\hline 10 & WORKING IN GROUPS ENHANCED OUR COMMUNICATION SKILLS & 32 & 4.25 & 672 \\
\hline 11 & WORKING IN GROUPS IMPROVED OUR PERFORMANCE & 32 & 3.91 & 0.856 \\
\hline 12 & $\begin{array}{l}\text { WORKING IN GROUPS HELPED US TO PARTICIPATE ACTIVELY IN THE } \\
\text { TEACHING/LEARNING PROCESS }\end{array}$ & 32 & 3.97 & 0.861 \\
\hline 13 & $\begin{array}{l}\text { WORKING IN GROUPS IS A WASTE OF TIME AS WE KEEP EXPLAINING THINGS TO OTHERS } \\
\text { (RECODE }\end{array}$ & 32 & 3.25 & 1.191 \\
\hline 14 & $\begin{array}{l}\text { WORKING IN GROUPS MAKES IT DIFFICULT GETTING MEMBERS TO ACTIVELY } \\
\text { PARTICIPATE IN TASKS }\end{array}$ & 32 & 3.53 & 1.367 \\
\hline 15 & WORKING IN GROUPS SHOULD BE ENCOURAGED/CONTINUED & 32 & 3.94 & 1.076 \\
\hline 16 & HAVING COMPLETED GROUP PROJECTS, I FEEL I AM MORE COOPERATIVE IN MY WRITING & 32 & 3.72 & 1.114 \\
\hline 17 & $\begin{array}{l}\text { HAVING COMPLETED GROUP PROJECTS, I FEEL I AM MORE CONFIDENT TO WORK WITH } \\
\text { OTHER STUDENTS }\end{array}$ & 32 & 3.75 & 0.95 \\
\hline 18 & $\begin{array}{l}\text { WORKING IN GROUPS ENABLED US TO USE SKILLS WHICH INDIVIDUAL ASSESSMENTS DO } \\
\text { NOT }\end{array}$ & 32 & 3.81 & 1.091 \\
\hline 19 & $\begin{array}{l}\text { WHILE WORKING IN GROUPS, ALL GROUP MEMBERS CONTRIBUTED EQUALLY TO THE } \\
\text { PROJECT }\end{array}$ & 32 & 3.31 & 1.33 \\
\hline 20 & WE SOMETIMES DISAGREED ABOUT WHAT TO SAY OR HOW TO EXPRESS OUR IDEAS & 32 & 3.59 & 0.837 \\
\hline 21 & DESPITE DISAGREEMENT, THE GROUP WAS ABLE TO REACH AGREEMENT & 32 & 3.28 & 1.276 \\
\hline 22 & I LEARNED NEW WAYS TO PLAN MY PARAGRAPH FROM THE GROUP & 32 & 3.84 & 1.019 \\
\hline 23 & I HAD THE CHANCE TO EXPRESS MY IDEAS IN THE GROUP & 32 & 4.03 & 0.782 \\
\hline 24 & $\begin{array}{l}\text { WHILE WORKING IN GROUPS, WE SPENT MORE TIME PLANNING THAN I DO WHEN I } \\
\text { WRITE ALONE }\end{array}$ & 32 & 3.91 & 1.174 \\
\hline 25 & $\begin{array}{l}\text { WHILE WORKING IN GROUPS, WE SPENT MORE TIME GENERATING IDEAS THAN I DO } \\
\text { WHEN I WRITE ALONE }\end{array}$ & 32 & 3.78 & 1.07 \\
\hline 26 & $\begin{array}{l}\text { WHILE WORKING IN GROUPS, WE SPENT MORE TIME CHECKING SPELLING, } \\
\text { PUNCTUATION AND GRAMMAR THAN I DO WHEN I WRITE ALONE }\end{array}$ & 32 & 3.38 & 1.238 \\
\hline 27 & $\begin{array}{l}\text { WHILE WORKING IN GROUPS, WE SPENT MORE TIME REVISING THAN I DO WHEN I } \\
\text { WRITE ALONE }\end{array}$ & 32 & 3.66 & 0.937 \\
\hline 28 & I LEARNED NEW WAYS TO SUPPORT MY POINTS OF VIEW & 32 & 3.84 & 0.954 \\
\hline
\end{tabular}




\begin{tabular}{|c|c|c|c|c|}
\hline \multicolumn{5}{|c|}{ Continued } \\
\hline 29 & I ENJOY WRITING MORE THAN I DID BEFORE DUE TO COLLABORATIVE WRITING & 32 & 3.59 & 1.132 \\
\hline 30 & I GET MORE WORK DONE WHEN I WORK WITH OTHERS & 32 & 3.88 & 0.942 \\
\hline 31 & $\begin{array}{l}\text { THE GROUP PRODUCED A BETTER DESCRIPTION AND A STORY AS COMPARED TO } \\
\text { INDIVIDUAL WRITING }\end{array}$ & 32 & 3.97 & 0.897 \\
\hline 32 & OVERALL, THIS WAS A WORTHWHILE EXPERIENCE & 32 & 4.22 & 0.87 \\
\hline
\end{tabular}

Similarly item 6 rating $(\mathrm{m}=4.31)$ while item $10(\mathrm{~m}=4.25)$. Item 6 reports on working in groups help to receive useful feedback and item 10 reports on working in groups enhance communication skills. This brings into line of a study conducted by Bijami et al. The study supports peer feedback has a great impact on writing skill, it aids in improving of the skill. Feedback creates awareness among students in order to identify problems in writings (Barnawi, 2010). Aliyu (2007) states the integration of collaborative learning as instructional method cultivates social skills. As Vygotsky's (1978) learning theory suggested a child cognitively progress through social interaction. According to Tamimi \& Attamimi (2014) collaborative writing creates a maximum space to improve speaking proficiency.

Item 32 it points out that collaborative learning was a worthwhile experience for students. Its mean score rating is $(\mathrm{m}=4.22)$ which is consider high. Item 23 $(\mathrm{m}=4.03)$ address expression of idea, Rokhaniyah (2016) states collaborative learning allows students to express relevant ideas followed by evidence or reason to support their argument. Meanwhile about 34\% respondents with the mean rating $(\mathrm{m}=4)$ strongly agreed that collaborative learning capable to assist weaker learners. Item 12 and 31 receive similar rating $(\mathrm{m}=3.97)$. Item 12 indicates working in groups help students to participate actively in the teaching and learning process. This agreed to the study conducted by Alhabeedi (2015) when students are actively involved while working in a cooperative atmosphere, the learning seems to be effective. Item 31 indicates the group produces a better description and a story as compared to individual writing. This is in line with Arifin \& Anwar (2018) study. They asserted that collaborative writing strategy is a technique used to improve descriptive writing.

While item 15 (working in groups should be encouraged/continued) obtains rating $(\mathrm{m}=3.94)$ Cooperative learning can increase the level of motivation, boost confidence and students' interest in learning. While item $24(\mathrm{~m}=3.91)$ students get to do more planning compared to individual writing. In collaborative learning, students receive immediate feedback from peers which will be helpful in planning, while in individual planning peer feedback is absent (Jalili \& Shahrokhi 2017). Item 13 mean rating is $(\mathrm{m}=3.91)$, working in groups improve performance. This is supports the study conducted by Chiriac (2014), learning in groups not just lead to knowledge acquisition but promote academic high performance.

As for item 2 and $30(\mathrm{~m}=3.88)$ got high rating respectively. Item 2 (Working 
in groups fostered exchange of knowledge, information and experience) Laal (2012) it explains the main feature of collaboration learning is to provide space for transmission of knowledge. Item 30 the respondents agree that more work done in group. Item $18(\mathrm{~m}=3.88)$ allows students employ skills which is not happen in individual work. Communication skill is essential in cooperative work. Item 22 and 28 obtained mean ratings $(\mathrm{m}=3.84)$ respectively, students learn process based writing according to the stages (planning, drafting, revising and editing). Item 28 addresses the students learned new ways to support their points of view.

Similarly item 5 and 17 obtained mean ratings as $(\mathrm{m}=3.75)$. Item 17 students feel confident, According to Talib \& Cheung (2017) students feel motivated through the outcome of collaborative learning thus increases self-confidence. Students feel working in groups help to create a more relaxed atmosphere. For item 1 and 16 the rating are $(m=3.72)$. K Scyer $(2016)$ suggested collaborative learning approach is essential to increase students' understanding. Item 16 explains students feel more cooperative. A positive interdependence among members will make one feels cooperative. While item $25(\mathrm{~m}=3.78)$ addresses that ideas expression in groups and spending more time on generating ideas.

Item $7 \& 8$ obtained moderate rating $(\mathrm{m}=3.69)$. Item $20(\mathrm{~m}=3.59)$, item 14 $(\mathrm{m}=3.53)$. The least rating items are Item $19(\mathrm{~m}=3.31), 21(\mathrm{~m}=2.28)$ and item $13(\mathrm{~m}=3.25)$. The least rating simplify the ineffective collaborative approach. There few reasons associated to this. According to Le et al. (2017) in group work, dominance occurs. It is the state where the smarter peers contribute more the than less competent students. The less competent students have low confidence and feel inferior to talk in a discussion.

From the survey results, most of the respondents (88\%) showed positive attitudes towards the incorporation of collaborative writing. Working in group is helpful while doing writing task. The findings of Talib and Cheung (2017) revealed students become better writers with the help of collaborative writing. A study conducted by Grief (2007) revealed that collaborative writing is a supportive approach. It is helpful to highlight one's strength and weakness. Therefore, this approach capable to shift the emphasis from individual weakness to a combined strength of a group.

About of respondents agreed that collaboration enhances learning process and understanding. Tao (2010) peer collaboration is a strategy used to investigate students understanding. The finding agrees with a study conducted by Adolphus \& Omeodu (2016) agreed that collaborative learning approach also gives impact on students learning and tend to perform better. It also suggested collaborative learning technique affects students understanding. The data also reveals that $67 \%$ of the respondents prefer to write in a group than individually. This corresponds with Jalilie \& Shahrokhi's study, which indicates that students showed positive attitudes towards collaborative attitudes.

Furthermore, the study illustrates that about $46.9 \%$ strongly agreed that collaborative learning makes problem solving easier. This aligns with Farrah (2011) 
research. His study highlighted problem solving strategies are enhanced via collaborative learning. The result is in agreement with Gohkale (1995) study, Collaborative learning significantly affects on students critical thinking. This was also proposed by Vygotsky (1978) in his learning theory students who work in a cooperative environment tend to perform at higher thinking level compared to the one who work independently. Furthermore in the present study, the approach collaboration provided space for students to receive useful feedback. This is in line with Barnawi (2010).

However, collaborative learning may turn out to be unsuccessful too. From the findings, it can be claimed that collaborative writing faces challenges in making sure of the students involvement to the maximum level. This is due to the presence of one or two passive learners in the group. These passive learners tend to depend on the active member for task completion. Some may feel inferior to start discussion or feel that ideas shared might be accepted. This statement aligns with Ajmi \& Ali (2014). These challenges can be tackled through the implementation of right strategies in teachers' instruction according to students learning styles.

\section{Conclusion}

\subsection{Summary}

Generally, the incorporation of collaborative approach into writing is supportive in ESL classroom. As for this study, it is investigating students' attitudes towards collaborative writing. The findings show positive responses which is similar with a number past studies. The study elicits that the use of collaborative writing facilitates effectiveness in learning. The evidence of this study supports that collaborative writing offers positive outcomes. There are certain benefits experienced while working collaboratively. Moreover, the attitude perceived by the students will help teachers to design writing activities to cater students accordingly. In addition to that, in the present days, the educational needs increase as per demand of the $21^{\text {st }}$ century learning aspects. Therefore, a variety of strategies and approaches will address the shift in teaching and learning styles.

\subsection{Implications}

This study offers an overview of the effectiveness of collaborative writing at secondary school level. A number of areas of further research are readily apparent. The implications of this study are as follows. Firstly, the study was carried out in a classroom setting. Therefore, the sample size is small. It included only 32 students from the researcher's own class. Future researchers may escalate this sample size by including students from a greater number of classes. This study only focused on form 2 students. The future research may look at different level of classes. This will help to increase the generalizability of the results. This study solely depends on questionnaires to collect data. An interview can be used to gather more findings. Interviews are helpful to gain depth information. Besides 
that, a replication of this study can be carried out pertaining other language skills, such reading, speaking and listening. Another implication to be listed is a study students can be carried out. An observation technique is recommendable. It is followed by a checklist that can be applied for future studies.

\section{Conflicts of Interest}

The authors declare no conflicts of interest regarding the publication of this paper.

\section{References}

Ajmi, A., \& Ali, I. H. (2014). Collaborative Writing in Group Assignments in an EFL/ESL Classroom. English Linguistics Research, 3, 1-17. https://doi.org/10.5430/elr.v3n2p1

Bijami, M., Kashef, S. H., \& Nejad, M. S. (2013). Peer Feedback in Learning English Writing: Advantages and Disadvantages. Journal of Studies in Education, 3, 91-97. https://doi.org/10.5296/jse.v3i4.4314

Bulut, P. (2017). The Effect of Primary School Students' Writing Attitudes and Writing Self-Efficacy Beliefs on Their Summary Writing Achievement. International Electronic Journal of Elementary Education, 10, 281-285.

https://doi.org/10.26822/iejee.2017236123

Chitravelu, N., Sithamparam, S., \& Teh, S. C. (2005). ELT Methodology: Principles and Practice. Shah Alam: Penerbit Fajar Bakti.

Dale, H. (1997). Co-Authoring in the Classroom. Creating an Environment for Effective Collaboration.

Fareed, M., Ashraf, A., \& Bilal, M. (2016). ESL Learners' Writing Skills: Problems, Factors and Suggestions. Journal of Education and Social Sciences, 4, 82-93. https://doi.org/10.20547/jess0421604201

Farrah, M. (2011). Attitudes towards Collaborative Writing among English Majors in Hebron University. Arab World English Journal, 2, 136-170.

Hashemian, M., \& Heidari, A. (2013). The Relationship between L2 Learners' Motivation/Attitude and Success in L2 Writing. Procedia-Social and Behavioral Sciences, 70, 476-489. https://doi.org/10.1016/j.sbspro.2013.01.085

Le, H., Janssen, J., \& Teoh, W. (2017). Collaborative Learning Practices: Teacher and Student Perceived Obstacles to Effective Student Collaboration. Cambridge Journal of Education, 48, 103-122. https://doi.org/10.1080/0305764X.2016.1259389

Mandusic, D., \& Blaskovic, L. (2015). The Impact of Collaborative Learning to Critically Thinking. Trakia Journal of Sciences, 13, 426-428. https://doi.org/10.15547/tjs.2015.s.01.073

Nunan, D. (1989). Designing Tasks for the Communicative Classroom. Cambridge: Cambridge University Press.

Sharma, G. (2017). Pros and Cons of Different Sampling Techniques. International Journal of Applied Research, 3, 749-752.

Storch, N. (2001). How Collaborative Is Pair-Work? ESL Tertiary Students Composing in Pairs. Language Teaching Research, 5, 29-53. https://doi.org/10.1177/136216880100500103

Sukirman, S. (2016). Using Collaborative Writing in Teaching Writing. Journal of the Association Arabic and English, 2, 33-46. 
Talib, T., \& Cheung, Y. L. (2017). Collaborative Writing in Classroom Instruction: A Synthesis of Recent Research. The English Teacher, 46, 43-57.

Vygotsky, L. (1978). Mind in Society. London: Harvard University Press. 